\title{
Plant density on yield of Husk tomato (Physalis ixocarpa Brot.) in field and greenhouse
}

\author{
Bernabé Ignacio Ramos-López ${ }^{1}$ (D) Yolanda Donají Ortiz-Hernández ${ }^{1^{*} \text { (D) }}$ \\ ${\text { Isidro } \text { Morales }^{1} \text { (D) Teodulfo Aquino-Bolaños }}^{1}$ (D)
}

${ }^{1}$ Instituto Politécnico Nacional, Centro Interdisciplinario de Investigación para el Desarrollo Integral Regional Unidad Oaxaca (CIIDIROaxaca), 71230, Santa Cruz Xoxocotlán, Oaxaca, México. E-mail: yortiz@ipn.mx. "Corresponding author.

ABSTRACT: Physalis ixocarpa Brot. (tomatillo or Husk tomato) is one of the five major vegetables cultivated in Mexico, but its yield in the field is low. However, greenhouse crops and the enhancement in plant density can promote an increase in yield per area. The aim of this research was to evaluate: yield, water consumption and water use efficiency of variety husk tomato 'Diamante'. The experiment was conducted under field and greenhouse conditions, during the two crop cycles (autumn-winter and spring-summer), with different planting densities (1.5, 2 and 3 plants $\mathrm{m}^{-2}$ ), in complete random blocks and three replications. The yield was influenced by the planting density and environments. In both environments, the planting density, with 3 plants $m^{-2}$ increased yield $32 \%$, and $25 \%$ in water use efficiency (WUE). In greenhouse increased $32 \%$ yield $\mathrm{m}^{-2}$ and the WUE it was $18.1 \mathrm{~kg} \mathrm{~m}^{-3}$ while in the field was $16.4 \mathrm{~kg} \mathrm{~m}^{-3}$. Crop cycle spring-summer produced differences of $27 \%$ in plant length and $15 \%$ in stem diameter, probably due to the temperature that was $4{ }^{\circ} \mathrm{C}$ higher with respect to autumn-winter.

Key words: Diamond variety, horticultural crops, tomatillo, water use efficiency.

Densidade vegetal no rendimento de tomate Husk (Physalis ixocarpa Brot.) em campo e casa de vegetação

RESUMO: Physalis ixocarpa Brot. (tomatillo ou tomate de cáscara) é um dos cinco principais vegetais cultivados no México, mas seu rendimento no campo é baixo. No entanto, as culturas em estufa e o aumento da densidade das plantas podem promover um aumento no rendimento por área. O objetivo desta pesquisa foi avaliar: rendimento, consumo de água e eficiência no uso da água do tomate de casca de variedade 'Diamante'. O experimento foi conduzido em condições de campo e casa de vegetação, durante os dois ciclos de cultivo (outonoinverno e primavera-verão), com diferentes densidades de plantio (1,5, 2 e 3 plantas $\left.m^{-2}\right)$, em blocos aleatórios completos e três replicações. $O$ rendimento foi influenciado pela densidade e pelos ambientes de plantio. Nos dois ambientes, a densidade de plantio, com três plantas $m^{-2}$, aumentou a produtividade em $32 \%$ e em $25 \%$ na eficiência no uso da água (WUE). Em casa de vegetação aumentou $32 \%$ do rendimento ${ }^{-2}$ e o WUE foi de $18,1 \mathrm{~kg} \mathrm{~m}^{-3}$, enquanto no campo foi de $16,4 \mathrm{~kg} \mathrm{~m}^{-3}$. O ciclo da safra primavera-verão produziu diferenças de $27 \%$ no comprimento das plantas e $15 \%$ no diâmetro do caule, provavelmente devido à temperatura $4{ }^{\circ} \mathrm{C}$ maior em relação ao outono-inverno.

Palavras-chave: Variedade de diamantes, culturas horticolas, tomatillo, eficiência no uso da água.

\section{INTRODUCTION}

Husk tomato (Physalis ixocarpa Brot.) is one of the most important crops for Mexican gastronomy; and therefore, for the vegetable sector of Mexico. It occupies fifth place in production volume and fourth in cultivated area (SIAP, 2018), after the following vegetables: chili (Capsicum annuum L.), potato (Solanum tuberosum L.), tomato (Solanum lycopersicon L.) and onion (Allium cepa L.). In 2018, the cultivated area was 41,336 ha with a yield of 19 $\mathrm{t} \mathrm{ha}^{-1}$ (SIAP, 2018). This yield is considered low due to inefficient water management (LÓPEZ-LÓPEZ et al., 2008), environmental factors and pests and diseases (SANTIAGUILLO-HERNÁNDEZ et al.,
2009), and because there is a lack of research in protected production agriculture systems (REIS et al., 2013; PEÑA-LOMELÍ et al., 2014; ARAUJO et al., 2016). There are also few studies on plant densities among other determining factors, that could possible increase yield and obtain the potential yield of $83.8 \mathrm{t}$ $\mathrm{ha}^{-1}$ mentioned by SOLDEVILLA-CANALES et al. (2002) for this crop.

In protected agriculture systems, it is of fundamental importance to determine plant or sowing density (VILLALOBOS et al., 2009) because is related to the number of plants or seeds to establish in a given area when the plantation frame or topological design varies and yield (PAPADOPOULOS \& ORMROD, 1990; AMUNDSON et al., 2012; PEÑA- 
LOMELÍ et al., 2014). Moreover, the species, variety, growth habit, climate, water availability, type of soil and production aim should be considered in order to use the available space efficiently and facilitate cultivation tasks such as weeding fumigation, training, pruning and harvest (VILLALOBOS et al., 2009; BARROSO et al., 2017).

The microclimate, fertilization and election of the suitable plant density favors interception of solar energy (HEUVELINK \& GONZÁLEZREAL, 2008), increases yield and irrigation water use efficiency (QIU et al., 2013). However, a higher plant density increases water consumption, and so it is necessary to assure the irrigation water supply especially during flowering. SILVA et al. (2019) mentioned low tomato yield (Solanum lycopersicon L.) when irrigation is suspended, due to abortion of flowers and fruits. CASTILLO-CÉREZ et al. (1992) obtained the highest yield and fruit quality of $P$. ixocarpa trained on trellises with 5 plants $\mathrm{m}^{-2}$ in the field. Under conditions of greenhouse and hydroponics, RAMOS-LÓPEZ et al. (2018) reported on $P$. ixocarpa higher yield with a density of 1.5 plants $\mathrm{m}^{-2}$ a yield in greenhouse $2.73 \mathrm{~kg} \mathrm{~m}^{-2}$, while SOLDEVILLA-CANALES et al. (2002) obtained on P. ixocarpa $2.5 \mathrm{~kg} \mathrm{~m}^{-2}$ with a density of 3.3 plants $\mathrm{m}^{-2}$, using trellises to support the plants, mulch on the soil and a supply of $\mathrm{CO}_{2}$ to the soil. However, PEÑALOMELÍ et al. (2014) cultivated P. ixocarpa in the field and in greenhouse and obtained better results in the field with a density of 2 plants $\mathrm{m}^{-2}$.

Based on these facts, this study evaluated three plant densities under field and greenhouse conditions, and their effect on water consumption, growth and productive parameters of $P$. ixocarpa.

\section{MATERIALS AND METHODS}

The study was conducted in Santa Cruz Xoxocotlan, Oaxaca, Mexico $\left(17^{\circ} 1^{\prime} 31^{\prime \prime} \mathrm{N}\right.$ and $96^{\circ}$ 43' 11" W, altitude $1518 \mathrm{~m}$ ), during the autumnwinter (AW-2016-2017) and spring-summer (SS2017) growing cycles. We used the husk tomato variety 'Diamante' (hybrid obtained from the variety CHF1 Chapingo and Puebla SM3, by Universidad Autónoma Chapingo, Mexico with registration TOM-002-170908 in CNVV- SNICS-SAGARPA). This early semi-erect variety produces large bright green fruits (with three locules); it is medium firm and has a short shelf life. Seeds are brownish-yellow, and when it is cultivated with irrigation and mulch, it can produce $30 \mathrm{t} \mathrm{ha}^{-1}$ (PEÑA-LOMELÍ et al., 2018).

Seeds were germinated in polystyrene trays with 200 cavities $18.7 \mathrm{cc}$ volume. We used a mixture of $3: 1 \mathrm{v} / \mathrm{v}$ of the organic substrate Sunshine Mix-3 (Sun Gro ${ }^{\circledR}$ Horticulture, MA, USA) and agrolite (Agrolita $^{\circledR}$ de México S.A. de C.V.).

Water and soil at the site were analyzed in accordance with the Official Mexican Norm NOM021-RECNAT-2000 (SEMARNAT, 2003). The physical properties of the soil were the following: sandy texture, bulk density $1.55 \mathrm{~g} \mathrm{~cm}^{-3}$, field capacity $8.5 \%$, wilting point $3.5 \%$, basic infiltration $6.3 \mathrm{~cm} \cdot \mathrm{h}^{-}$ ${ }^{1}$ and organic matter $1.6 \%$. Results of the chemical analysis were $\mathrm{pH} 7.6$, macro-elements $\left(\mathrm{mg} \mathrm{kg}^{-1}\right)$ : N (12), P (92), K (142), Ca (4318), $\mathrm{Mg}$ (350) and $\mathrm{SO}_{4}$ (253), and microelements ( $\left.\mathrm{mg} \mathrm{kg}^{-1}\right)$ : B (2.0), $\mathrm{Cu}$ (4.4), Fe (211), Mn (90), Zn (3.2) and Na (195). Analysis of the water revealed $\mathrm{pH} 7.82$ and $\mathrm{CE} 0.85 \mathrm{dS} \mathrm{m}^{-1}$, macro-elements (meq L-1) Ca (4.51), Mg (1.56), K (0.05), $\mathrm{SO}_{4}$ (1.18), $\mathrm{NO}_{3}$ (1.60), and microelements (mg L-1) B (0.31).

Fertigation was delivered through a drip tape with emitter's $0.20 \mathrm{~m}$ apart, flow of 1.9 $\mathrm{L} \mathrm{h}^{-1}$ and operation pressure of the system at 1.5 $\mathrm{kg} \mathrm{cm}^{-2}$ (HERRERA et al., 2013). The nutritive solution used was adjusted to that recommended by URRESTARAZU (2004) for tomato (Solanum lycopersicon L.) and RAMOS-LOPEZ et al. (2018) for husk tomato (P. ixocarpa) taking the soil and water analyses into account.

The volume of irrigation water supplied was measured with the volumetric method (VILLALOBOS et al., 2009). The total irrigated volume in each crop cycle was divided by the area of each environment and the water spending was obtained in $\mathrm{L} \mathrm{m} \mathrm{m}^{-2}$, divided by the plant density to determine the amount in liters applied to each plant (RAMOS-LÓPEZ et al., 2018). Water use efficiency (WUE) of the plants expressed in $\mathrm{kg} \mathrm{m}^{-3}$ (DROOGERS \& KITE, 1999).

The crop was established in two environments: field and greenhouse. A greenhouse, covered with $200 \mu \mathrm{m}$ thick transparent polyethylene. Ventilation was passive by using hand-powered windows: one towards the Zenith and two on the sides. Side windows allowed the entrance of bees and insects into the greenhouse (RAMOS-LÓPEZ et al., 2018). The field plot had the same dimensions as the greenhouse. A beehive (Apis mellifera) was placed according to RAMOS-LÓPEZ et al. (2018). In both environments, we established four crop beds $(1 \times 23 \times 0.30 \mathrm{~m})$ in the soil with bicolor silver-black plastic mulch. The distance between beds was $2.5 \mathrm{~m}$ (Figure 1). In the autumn-winter cycle seedlings were transplanted to field crop beds on October 18, 2016 and in the spring-summer cycle on May 13, 2017 (in 


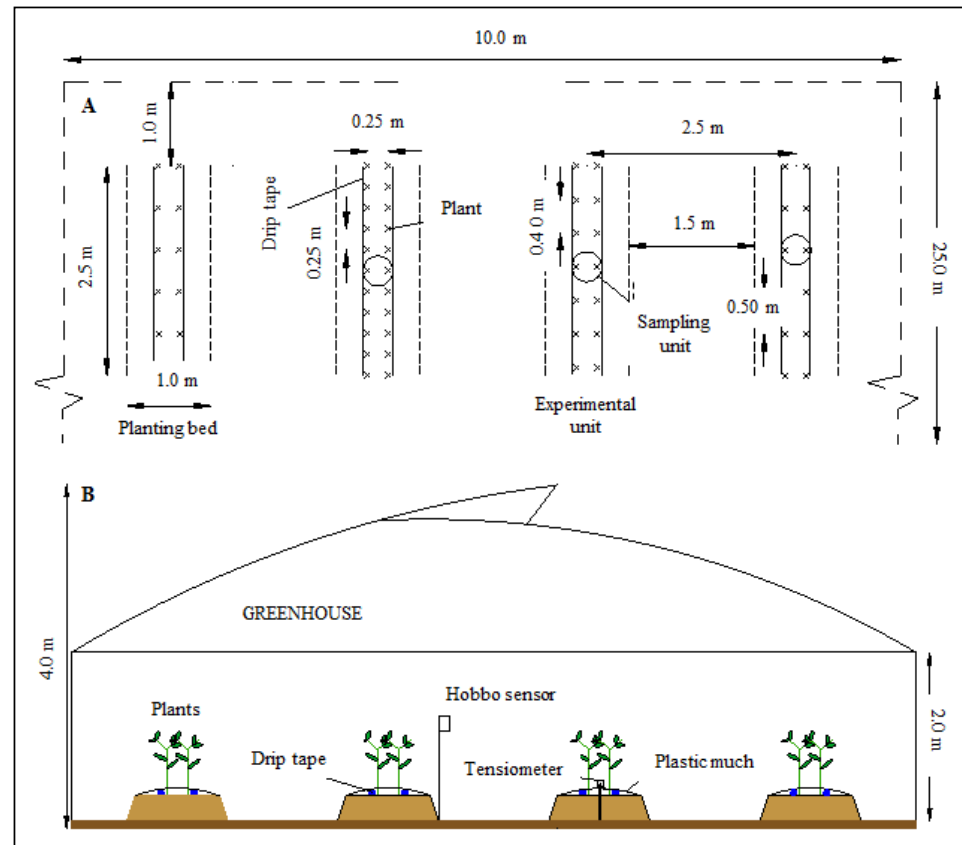

Figure 1 - Husk tomato in open-field and greenhouse. A) plant spatial distribution, B) front view. Santa Cruz Xoxocotlan, Oaxaca, Mexico. 2016/17.

both crop cycles, after 30 days of sowing). We tested three plant densities $\left(1.5,2\right.$ and 3 plants $\left.\mathrm{m}^{-2}\right)$ in double rows $0.25 \mathrm{~m}$ apart and $0.25,0.40$ and $0.50 \mathrm{~m}$ between plants. The plants were not tutored (supported), and the branches grew horizontally, eventually covering the area between beds. The experiment was a complete randomyzed block design with three replications. The experimental unit consisted of 10 plants.

Temperature and relative humidity of the air were recorded with a HOBO U23 Pro v2 Temperature/Relative Humidity Data Logger $\left(\mathrm{HOBO}^{\circledR}\right.$ PRO V2 ONSET, MA, USA) placed 1.20 $\mathrm{m}$ above soil level (four devices distributed inside and four outside the greenhouse); these data were recorded every five minutes (Figure 2).

In both environments, soil moisture was monitored daily by tensiometers placed in the soil 0.15 and $0.30 \mathrm{~m}$ deep (VILLALOBOS et al., 2009), was maintained between -10 and $-30 \mathrm{kPa}$ (THOMPSON et al., 2006). Fruits were picked when they reached physiological maturity, that is, when the fruit had a lime green color and filled and broke the calix (Figure 3E), seven harvests were made.

The morphometric variables were: plant length (Black \& Decker Stanley metal flex meter), stem diameter (at the middle part of the first branch), equatorial diameter and length of fruit, measured with a digital vernier (Mitutoyo 500-473 Il, USA). Plant length and stem diameter were registered after the last picking, and fruit equatorial and longitudinal diameters at each picking. Fruits were counted, weighted on a digital scale (O'Haus Pionner ${ }^{\circledR}$ st Corporation, USA), and measured on their equatorial diameter (according to the norm NMXFF-054-1982, for size and equatorial fruit diameter). Total yield per plant was obtained from the sum of the seven pickings, dividing weight of fruits from each picking by the number of plants per experimental unit, then multiplying by plant density to convert to yield per unit of area.

The data obtained were subjected to analysis of variance and means compared by Tukey's test $(P \leq 0.05)$ using the statistical software $\mathrm{SAS}^{\circledR}$ version 9.0 (SAS, 2002), and graphs were constructed using Microsoft ${ }^{\circledR}$ Excel.

\section{RESULTS AND DISCUSSION}

The comparison of means $(P \leq 0.05)$ showed that the increase in plant density of 1.5 to 3 plants $\mathrm{m}^{-2}$ reduced yield per plant by $34 \%$. However, the yield per $\mathrm{m}^{-2}$ increased $25 \%$ due to the larger number of plants (Table 1). The same behavior was reported for P. ixocarpa var. Rendidora and Tecozautla (RAMOS- 

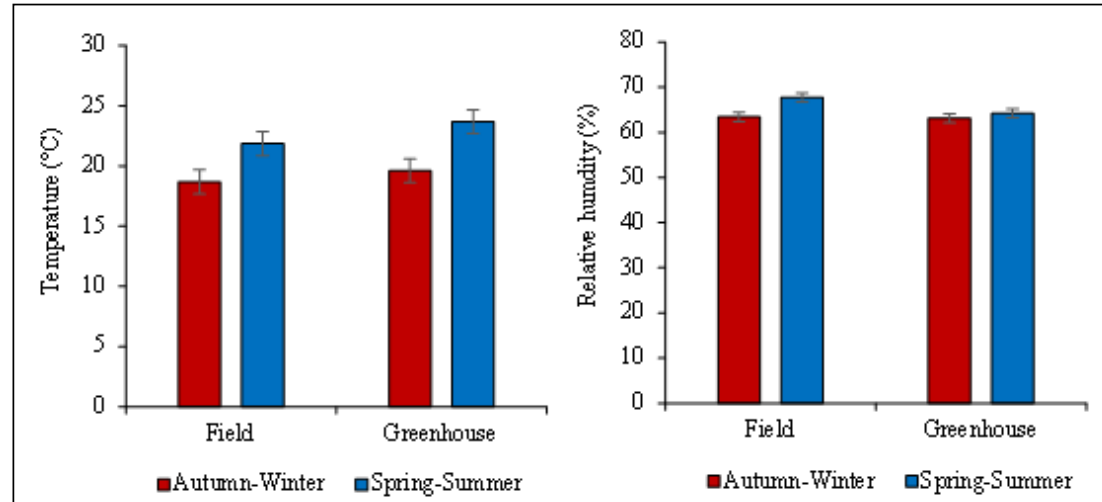

Figure 2 - Average air temperature and relative humidity during crop cycle of Husk tomato in two environments. Santa Cruz Xoxocotlan, Oaxaca, Mexico. 2016/17.

LÓPEZ et al., 2017, 2018), for Solanum lycopersicon L. (QIU et al., 2013) and Persea americana Mill. (MENZEL \& LAGADEC, 2014). In this regard, GLIESSMAN (2002) mentioned that plants compete for space, water, light and nutrients, and this competition is manifested by reductions in plant growth and yield. Therefore, the lower the density the better the source/demand relationship, which

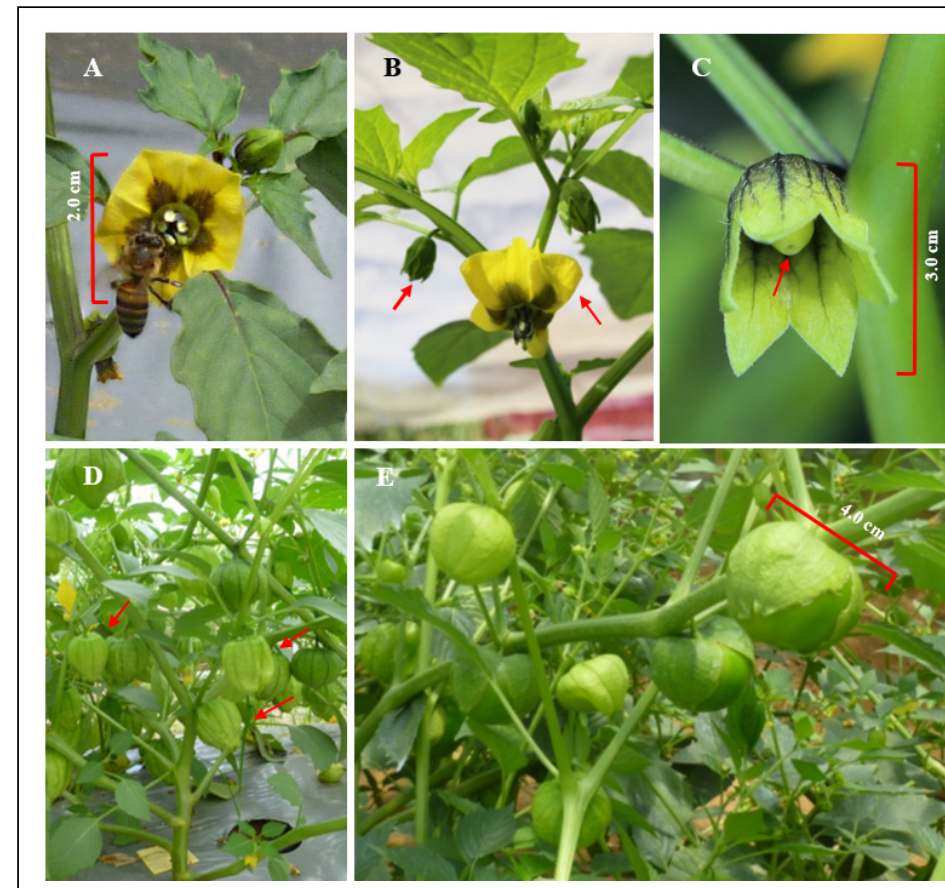

Figure 3 - Flower and fruit of P. ixocarpa Brot. A) Apis mellifera pollinating a full expanded and mature flower. B) Flower bud and open flower with corolla upwards to expose the stamens and stigma. C) Young fruit inside the calyx (husk). D) Fully developed chalice (serves to protect the fruit during its growth). E) Mature fruits, can be harvested when the calyx becomes disruption. Santa Cruz Xoxocotlan, Oaxaca, Mexico. 2016/17. 
Table 1 - Effect of plantation density, environments and crop cycles on productive characters, growth and water use efficiency of $\boldsymbol{P}$. ixocarpa. Santa Cruz Xoxocotlan, Oaxaca, Mexico. 2016/17.

\begin{tabular}{|c|c|c|c|c|c|c|c|c|}
\hline & \multirow{3}{*}{$\begin{array}{l}\mathrm{PL} \\
\mathrm{cm}\end{array}$} & \multirow{3}{*}{$\begin{array}{l}\mathrm{SD} \\
\mathrm{cm}\end{array}$} & \multirow{3}{*}{$\begin{array}{l}\text { WUE } \\
\mathrm{kg} \mathrm{m}^{-3}\end{array}$} & \multicolumn{3}{|c|}{--------------------Fruits--------------------- } & \multicolumn{2}{|c|}{------------Yield------------ } \\
\hline & & & & FW & ED & LF & $\mathrm{kg}_{\text {plant }}{ }^{-1}$ & $\mathrm{~kg} \mathrm{~m}^{-2}$ \\
\hline & & & & $\mathrm{g}$ & $\mathrm{cm}$ & $\mathrm{cm}$ & & \\
\hline \multicolumn{9}{|c|}{ 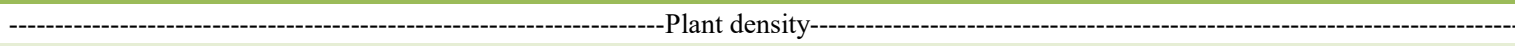 } \\
\hline 1.5 & $152.87 \mathrm{a}$ & $1.46 \mathrm{a}$ & $14.80 \mathrm{~b}$ & $31.18 \mathrm{a}$ & $4.12 \mathrm{a}$ & $3.30 \mathrm{a}$ & $2.42 \mathrm{a}$ & $3.64 \mathrm{~b}$ \\
\hline 2 & $150.71 \mathrm{a}$ & $1.34 \mathrm{~b}$ & $17.41 \mathrm{ab}$ & $28.43 \mathrm{a}$ & $3.96 \mathrm{a}$ & $3.19 \mathrm{a}$ & $2.10 \mathrm{ab}$ & $4.20 \mathrm{~b}$ \\
\hline 3 & $139.97 \mathrm{a}$ & $1.21 \mathrm{c}$ & $19.66 \mathrm{a}$ & $31.17 \mathrm{a}$ & $4.01 \mathrm{a}$ & $3.28 \mathrm{a}$ & $1.60 \mathrm{~b}$ & $4.81 \mathrm{a}$ \\
\hline DMS & 31.44 & 0.20 & 4.24 & 6.48 & 0.21 & 0.22 & 0.52 & 1.08 \\
\hline \multicolumn{9}{|c|}{ 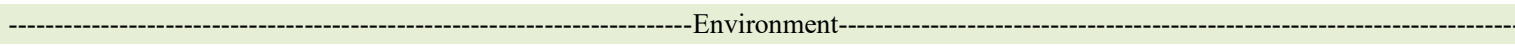 } \\
\hline Field & $123.85 \mathrm{~b}$ & $1.37 \mathrm{a}$ & $16.41 \mathrm{a}$ & $29.90 \mathrm{a}$ & $4.00 \mathrm{a}$ & $3.26 \mathrm{a}$ & $1.75 \mathrm{~b}$ & $3.63 \mathrm{~b}$ \\
\hline Greenhouse & $171.84 \mathrm{a}$ & $1.30 \mathrm{a}$ & $18.17 \mathrm{a}$ & $30.62 \mathrm{a}$ & $4.07 \mathrm{a}$ & $3.25 \mathrm{a}$ & $2.34 \mathrm{a}$ & $4.80 \mathrm{a}$ \\
\hline DMS & 21.19 & 0.13 & 2.86 & 4.37 & 0.11 & 0.15 & 0.35 & 0.72 \\
\hline \multicolumn{9}{|c|}{ 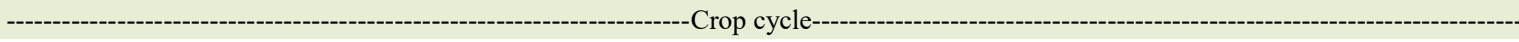 } \\
\hline Autumn-Winter & $130.00 \mathrm{~b}$ & $1.24 \mathrm{~b}$ & $17.33 \mathrm{a}$ & $30.29 \mathrm{a}$ & $4.10 \mathrm{a}$ & $3.26 \mathrm{a}$ & $1.94 \mathrm{a}$ & $3.98 \mathrm{a}$ \\
\hline Spring-Summer & $165.69 \mathrm{a}$ & $1.43 \mathrm{a}$ & $17.25 \mathrm{a}$ & $30.23 \mathrm{a}$ & $3.96 \mathrm{a}$ & $3.25 \mathrm{a}$ & $2.15 \mathrm{a}$ & $4.45 \mathrm{a}$ \\
\hline DMS & 21.19 & 0.13 & 2.86 & 4.37 & 0.21 & 0.15 & 0.35 & 0.72 \\
\hline
\end{tabular}

PL: Plant length; SD: Stem diameter; WUE: Water use efficiency; FW: Average fruit weight; ED: Equatorial diameter of fruit; LF: length of fruit; DMS: Significant minimum difference. Means followed by the same letter in the columns do not differ at 0.05 significant level by Tukey test.

produces higher yield per plant, similar to the yield obtained in Physalis ixocarpa by RAMOS-LÓPEZ et al. (2018). In our study, higher plant density reduced stem diameter by $17 \%$, probably because of greater competition for light among plants (GLIESSMAN, 2002). In this respect, MIELKE \& SCHAFFER (2010) mentioned that the reduction in stem diameter could be due to lower interception of light, which is directly related to photosynthetic activity. Conversely, higher plant density increased water use efficiency $(25 \%)$, which means an increase of five kilograms of fruit per $\mathrm{m}^{-2}$ similar to the water efficiency obtained in Maize by SANI et al. (2008).

Plants cultivated in greenhouse had significantly $(P \leq 0.05)$ longer plants $(38 \%)$ and higher yield per $\mathrm{m}^{-2}(32 \%)$ than the field-grown plants (Table 1). Longer plants and higher yields may be due to lower radiation inside the greenhouse than in the field and to a longer time with better climatological conditions during the day that allow the plants to carry out photosynthesis (QIU et al., 2013). Similar to the obtained under conditions of greenhouse and field in P. ixocarpa by RAMOS-LÓPEZ et al. (2018), SOLDEVILLA-CANALES et al. (2002) and Solanum lycopersicum by CARDOSO et al. (2018). Plants cultivated in spring-summer (SS) had higher values of plant length and stem diameter (Table 1), it is probably due to the $4{ }^{\circ} \mathrm{C}$ increase in temperature with respect to autumn-winter (AW), to the rains in the field, and higher relative humidity (Figure 2).

Water consumption in the greenhouse was 84 and $100 \mathrm{~L} \mathrm{plant}^{-1}$ in the AW and SS cycles, respectively (Figure 4A). Consumption of water in AW was similar to the $84 \mathrm{~L}$ water plant ${ }^{-1}$ in greenhouse obtained by RAMOS-LOPEZ et al. (2018) for P. ixocarpa var. Rendidora and Tecozautla. Water consumption was higher in the SS cycle when temperatures were higher and probably increased evapotranspiration inside the greenhouse (Figure 2), (HONDA et al., 2019). In the field, during the AW cycle, each plant consumed 76 L water plant ${ }^{-1}$, similar to that reported by RAMOSLOPEZ et al. (2018) for P. ixocarpa var. Rendidora and Tecozautla. In the AW cycle, because it rained, irrigation in the field was reduced. Rainwater was estimated taking as a reference plant water consumption during the AW cycle in each environment, plus the volume registered inside the greenhouse during the SS cycle (Figure 4A).

In both environments, when plant density increased, water use efficiency showed a positive linear trend $\left(\mathrm{R}^{2}=0.81\right.$ and 0.84 for greenhouse and field, respectively). It reached a maximum of 29.7 $\mathrm{kg} \mathrm{m}^{-3}$ in the macro-tunnel and of $18.53 \mathrm{~kg} \mathrm{~m}^{-3}$ in the field (Figure 4B). The increase in plant density in 


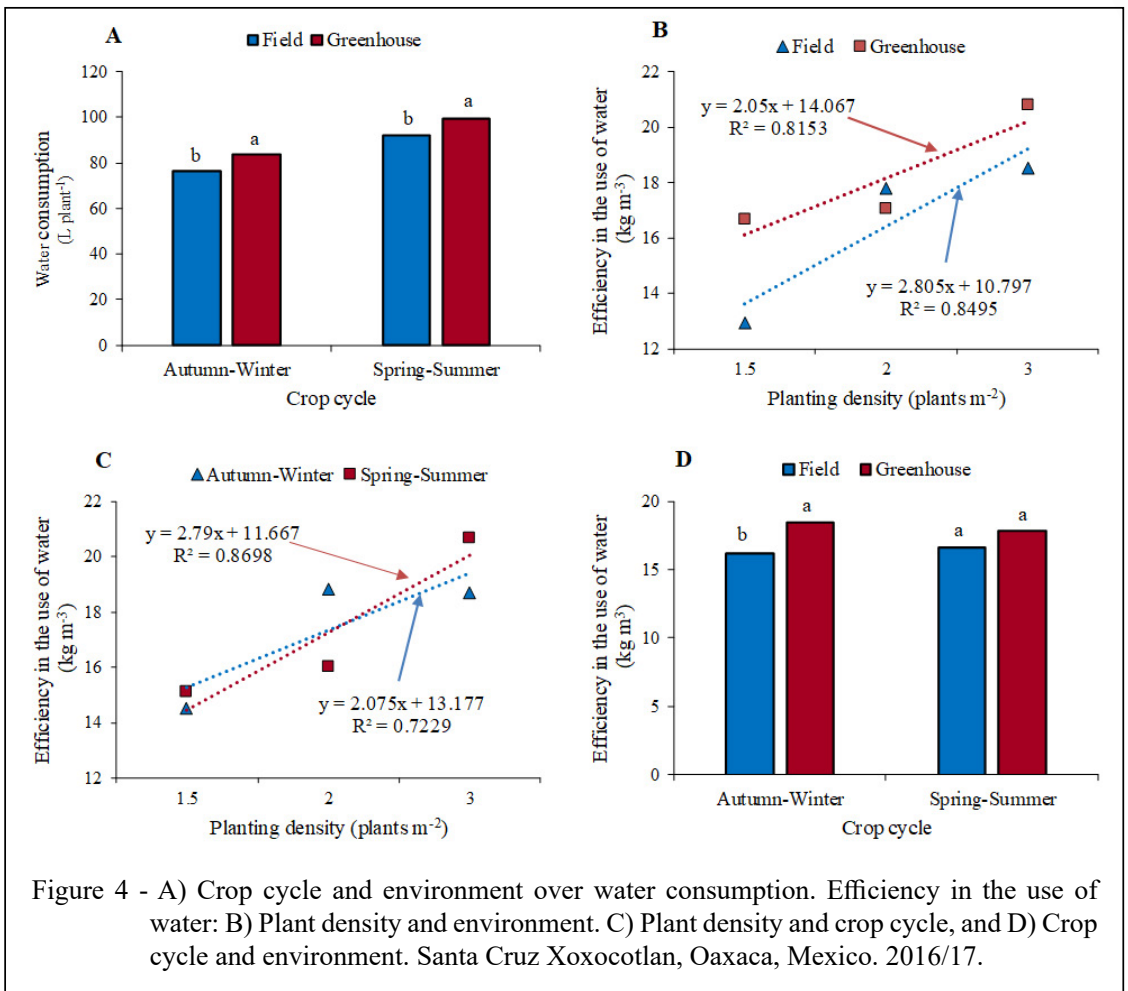

the two crop cycles showed an increase in WUE with a positive linear trend $\left(\mathrm{R}^{2}=0.72\right.$ and 0.86 for AW and SS, respectively), reaching a maximum value $\left(20.6 \mathrm{~kg} \mathrm{~m}^{-3}\right)$ in spring-summer (Figure $4 \mathrm{C}$ ) because of the better environmental conditions for the crop in that cycle (Figure 2). The effect of crop cycle and environment on WUE (Figure 4D) was not significant. The WUE in the field was 16.4 $\mathrm{kg} \mathrm{m}^{-3}$ and in the greenhouse it was $18.1 \mathrm{~kg} \mathrm{~m}^{-3}$, probably the microclimate inside condition of the greenhouse favored the WUE (RAMOS-LOPEZ et al., 2017, 2018).

\section{CONCLUSION}

High planting density caused smaller stems diameter and higher yield per $\mathrm{m}^{-2}$ and in water use efficiency. Plant length and yield per plant and per unit of area were higher in the greenhouse, as well as the longest plant length and largest stem diameter were in the spring-summer crop cycle.

\section{ACKNOWLEDGEMENTS}

The authors grateful to the Instituto Politécnico Nacional (IPN) for the facilities to accomplish this research. As well as the Consejo Nacional de Ciencia y Tecnología (CONACyT) for the scholarship of the first author.

\section{DECLARATION OF CONFLICTS OF INTERESTS}

The authors declare no conflict of interest. The founding sponsors had no role in the design of the study; in the collection, analyses, or interpretation of data; in the writing of the manuscript, and in the decision to publish the results.

\section{AUTHORS' CONTRIBUTIONS}

All authors contributed equally for the conception and writing of the manuscript. All authors critically revised the manuscript and approved the final version.

\section{REFERENCES}

AMUNDSON, S. et al. Optimizing planting density and production systems to maximize yield of greenhouse-grown 'trust' tomatoes. HortTechnology, v.22, n.1, p.44-48. 2012. Available from: $<$ https://journals.ashs.org/horttech/view/journals/horttech/22/1/ article-p44.xml>. Accessed: Dec. 12, 2018. doi:10.21273/ HORTTECH.22.1.44.

BARROSO, N. et al. Maturation stages of fruits and physiological seed quality of Physalis ixocarpa Brot. ex Hornem. Revista Brasileira de Fruticultura, v.39, n. 3, e-151. 2017. 10.1590/0100-29452017151. 
CARDOSO, F. B. et al. Yield and quality of tomato grown in a hydroponic system, with different planting densities and number of bunches per plant. Pesquisa Agropecuária Tropical, v.48, n.4, p.340-349. 2018, Available from: <http://www.scielo.br/scielo. php?script $=$ sci_arttext\&pid $=$ S1983-40632018000400340\&lng $=$ en\&nrm=iso $>$. Accessed: Jul. 18, 2019. doi.org/10.1590/198340632018v4852611.

DROOGERS, P.; KITE, G. Water productivity from integrated basin modeling. Irrigation and drainage systems, v.13, n.3, p.275-290, 1999. Available from: <https://link.springer.com/articl e/10.1023\%2FA\%3A1006345724659>. Accessed: Nov. 22, 2018 doi:10.1023/A:1006345724659.

ARAUJO, H. F. et al. Mini tomato production in organic system under greenhouse with partial control of meteorological elements. Revista Brasileira de Engenharia Agrícola e Ambiental, v.20, n.9, p.800-805, 2016. Available from: <http://www.scielo.br/ scielo.php?script $=$ sci_arttext\&pid $=\mathrm{S} 1415-43662016000900800>$. Accessed: Feb. 10, 2019. doi:10.1590/1807-1929/agriambi. v20n9p800-805.

GLIESSMAN, S.R. Agroecología. Procesos ecológicos en agricultura sustentable. LITOCAT tocat, CATIE, Turrialba, Costa Rica, 2002. 359p. Available from: <https://biowit.files.wordpress. com/.../agroecologia-procesos-ecolc3b3gicos-en-agricultur $>$. Accessed: Jul. 18, 2019.

HERRERA P. J.C. et al., 2013. Manual de capacitación de operadores. Con base en el estándar de competencias EC O348. Riego presurizado en parcelas. Instituto Mexicano de Tecnología del Agua. ISBN: 978-607-7563-98-3, Jiutepec, Morelos, México. 52p. Available from: <https://www.imta.gob.mx/biblioteca/ libros_html/manual-capacitacion-operadores/files/assets/common/ downloads/publication.pdf $>$. Accessed: Oct. 18, 2019.

HEUVELINK, E.; GONZÁLEZ-REAL， M.M. Innovation in plant-greenhouse interactions and crop management. Acta Horticulturae, v.801, p.63-74, 2008. Available from: <https:// www.ishs.org/ishs-article/801_2>. Accessed: Jul. 18, 2019. doi:10.1717660/ActaHortic.2008.801.2.

HONDA, E. A., et al. The relationship between plant density and survival to water stress in seedlings of a legume tree. Acta Botanica Brasilica, v.33, n.3, p.602-606. 2019. Available from:https://www scielo.br/pdf/abb/v33n3/0102-3306-abb-0102-33062018abb0432. pdf. Accessed: May, 15, 2020. https://doi.org/10.1590/0102$33062018 \mathrm{abb} 0432$.

LÓPEZ-LÓPEZ, R. et al. Husk tomato (Physalis ixocarpa Brot.) production based on irrigation volume and plastic mulching. Revista Chapingo Serie Horticultura, v.15, n.1, p.83-89, 2008 Available from: $<$ http://www.scielo.org.mx/scielo.php?script=sci arttext\&pid=S1027-152X2009000100012>. Accessed: Jun. 05, 2018. doi:10.5154/r.rchsh.2009.15.011.

MIELKE, M.S.; SCHAFFER, B. Photosynthetic and growth responses of Eugenia uniflora L. seedlings to soil flooding and light intensity. Environmental Experiment Botany, v.68, n.2 p.113-121, 2010. Available from: <https:/www.sciencedirect.com/ science/article/abs/pii/S0098847209002482>. Accessed: Jun. 15, 2020. https://doi.org/10.1016/j.envexpbot.2009.11.007.

MENZEL, C.M.; LAGADEC, M.D.I. Increasing the productivity of avocado orchards using high-density plantings: A review. Scientia Horticulturae, v.177, n.2, p.21-36, 2014. Available from: <https://
www.sciencedirect.com/science/article/pii/S0304423814003975>. Accessed: Jul. 18, 2019. doi:10.1016/j.scienta.2014.07.013.

PAPADOPOULOS, A.P.; ORMROD, D.P. Plant spacing effects on yield of the greenhouse tomato. Canadian Journal of Plant Science, v.70, n.2, p.565-573, 1990. Available from: <https://www. nrcresearchpress.com/doi/10.4141/cjps90-071\#.XUBf2-hKiUk>. Accessed: Jun. 10, 2019. doi:10.4141/cjps90-071.

PEÑA-LOMELÍ, A. et al. Agronomic performance of husk tomato varieties under greenhouse and open field conditions. Revista Fitotecnia Mexicana, v.37, n.4, p.381-391, 2014. Available from: $\quad<$ http://www.scielo.org.mx/scielo.php?script=sci arttext \&pid=S0187-73802014000400011>. Accessed: Jul. 18, 2019. doi:10.4141/cjps90-071.

PEÑA-LOMELÍ, A. et al. Manual pollination in two tomatillo (Physalis ixocarpa Brot. ex Horm.) varieties under greenhouse conditions. Revista Chapingo Serie Horticultura, v.34, n.1, p.4152, 2018. doi: 10.5154/r.rchsh.2017.02.011.

QIU, R. et al. Response of evapotranspiration and yield to planting density of solar greenhouse grown tomato in Northwest China. Agricultural Water Management, v.130, p.44-51, 2013. Available from: <https://www.sciencedirect.com/science/article/ pii/ S0378377413002229>. Accessed: Jul. 18, 2019. doi: 10.1016/j. agwat.2013.08.013.

RAMOS-LÓPEZ, B. I. et al. Consumo de agua y rendimiento de tomate de cáscara bajo diferentes cubiertas de invernaderos. Horticultura Brasileira, v.35, n.2, p.265-270, 2017. Available from: https://www.researchgate.net/publication/318556296 Consumo de agua y rendimiento de tomate de cascara bajo diferentes_cubiertas_de_invernaderos $>$. doi: $\overline{10.1590 / \mathrm{s} 0102-}$ 053620170218

RAMOS-LÓPEZ, B. I. et al. Yield analysis of Physalis ixocarpa Brot. ex Hornem varieties under greenhouse and field conditions. Ciência Rural v.48, n.11, p.1-7, 2018. Available from: <http:// www.scielo.br/scielo.php? script $=$ sci_abstract\&pid $=$ S010384782018001100401\&lng=en\&nrm $=$ iso $>$. Accessed. Oct. 18 2019. doi: $10.1590 / 0103-8478 \mathrm{cr} 20180044$

REIS, L.S. et al. Leaf area index and productivity of tomatoes under greenhouse. Revista Brasileira de Engenharia Agrícola e Ambiental, v.17, p.386-391, 2013. Available from: <http://www. scielo.br/pdf/rbeaa/v17n4/a05v17n4.pdf>. Accessed: Jul. 18, 2019. doi:10.1590/S1415-43662013000400005.

SANI, B.S. et al. Effect of irrigation and plant density on the growth, yield and water use efficiency of early maize in the Nigerian savanna. Journal of Agricultural and Biological Science. v.3, n.2, p. 2008. Available from: <https://www.researchgate.net/ publication/242077396_effect_of_irrigation_and_plant_density on_the_growth_yield_and_water_use_efficiency_of_early_ maize_in_the_Nigerian_savanna>. Accessed: May, 18, 2019.

SANTIAGUILLO-HERNÁNDEZ, J.F. et al. Aprovechamiento tradicional y moderno de tomate (Physalis ixocarpa Brot.) en México. Publicaciones de la red de tomate de cáscara. Folleto Técnico, 2. México, 2009. 31p. Available from: $<\mathrm{https}$ ://chapingo. $\mathrm{mx} /$ revistas/revistas/articulos/doc/rga-1418.pdf>. Accessed: Jul. $18,2019$.

SAS - Statistical Analysis System. User's guide statistics. 9th ed. Cary: SAS Institute, 2002. 943p. 
SEMARNAT. Secretaría de Medio Ambiente y Recursos Naturales. Especificaciones de fertilidad, salinidad y clasificación de suelos, estudios, muestreo y análisis. Diario Oficial de la Federación. Norma Oficial Mexicana NOM-021RECNAT-2000, ratificación 2003. Available from: <http://biblioteca.semarnat.gob.mx/janium/Documentos/Ciga/ libros2009/DO2280n.pdf $>$. Accessed: May, 19, 2020.

SIAP - Servicio de Información Agroalimentaria y Pesquera 2018. Available from: <http://www.siap.gob.mx/cierre-de-laproduccion-agricola-por-cultivo/> . Accessed: Feb.14, 2018.

SILVA, C.J. et al. Tomato yield as a function of water depths and irrigation suspension periods. Revista Brasileira de Engenharia Agrícola e Ambiental, v.23, n.8, p.591-597. 2019. <https://doi. org/10.1590/1807-1929/agriambi.v23n8p591-597>.

SOLDEVILLA-CANALES, S. et al. Application of $\mathrm{CO}_{2}$ to soil, use of plastic mulches, and management systems for husk tomatoes
(Physalis ixocarpa Brot.). Revista Chapingo serie Horticultura, v.8, n.1, p.25-38, 2002. Available from: <https://www.chapingo. $\mathrm{mx} /$ revistas/horticultura/contenido.php?id_articulo $=222 \& \mathrm{id}$ revistas $=1 \&$ id revista numero=12>. Accessed: Feb. 14, 2018. doi: 10.5154/r.rchsh.1999.06.040.

THOMPSON, R.B. et al. Evaluation of the Watermark sensor for use with drip irrigated vegetable crops. Irrigation Science, v.24, n.3, p.185-202, 2006. Available from: <https://link.springer.com/ article/10.1007/s00271-005-0009-5>. Accessed: Feb. 14, 2018. doi: 10.1007/s00271-005-0009-5.

URRESTARAZU, M. Tratado de cultivo sin suelo. $3^{\text {a }}$. Edición. Mundi-Prensa, Madrid, España, 2004. 914p.

VILLALOBOS, F.J. et al. Fitotecnia: Bases y tecnologías de la producción agrícola. $2^{\text {a }}$ edición. Mundi-Prensa. M. 2009. 


\section{Erratum}

In the article "Plant density on yield of Husk tomato (Physalis ixocarpa Brot.) in field and greenhouse" published in Ciência Rural, volume 51, number 1, DOI http://doi.org/10.1590/0103-8478cr20200992.

In the author's, where we read:

Bernabé Ignacio López-Ramos

Read:

Bernabé Ignacio Ramos-López 


\section{Erratum}

In the article "Plant density on yield of Husk tomato (Physalis ixocarpa Brot.) in field and greenhouse" published in Ciência Rural, volume 51, number 1, DOI http://doi.org/10.1590/0103-8478cr20200992.

In the DOI number, where we read:

http://doi.org/10.1590/0103-8478cr20200992

Read:

http://doi.org/10.1590/0103-8478cr20190992 